\title{
PENGGUNAAN HUKUM ADAT BAJO \\ SEBAGAI ALTERNATIF PENYELESAIAN PERKARA ANAK \\ PELAKU TINDAK PIDANA KESUSILAAN \\ (STUDI PADA MASYARAKAT ADAT BAJO, DI DESA JAYA \\ BHAKTIKECAMATAN PAGIMANA, KABUPATEN LUWUK \\ BANGGAI, SULAWESI TENGAH)
}

\author{
Julisa Aprilia Kaluku \\ Universitas Negeri Gorontalo (UNG), Fak. Ilmu Sosial Jurusan Ilmu Hukum \\ J1. Jenderal Soedirman No. 6, Kota Gorontalo \\ Email: chasfifer_07@yahoo.com
}

\begin{abstract}
Restorative Justice is the conflict solution which focus on recoverable original state. The child who did the crime, the Bajo tribal law to finish the problem. The purpose of the mediation conducted by customary law of Bajo is, returning the losses suffered by the victims, so their actions can be accounted. This research is field research or often called empiric law research, by using juridical sociology approach, analysis in this paper used descriptive qualitative, i.e. to describe clearly overall object to be studied in the field in order to achieve the clarity with problems that would be discussed. The result of study children who did morality criminal acts on Bajo custom society show that from the year of until 2010 until 2013 is about 41 person children did morality criminal acts, and all of the finishing process are done with custom.
\end{abstract}

Key words: restorative justice, children, criminal acts of indecency, bajo customary law

\begin{abstract}
Abstrak
Restorative Justice merupakan bentuk penyelesaian konflik yang mengedepankan pada terpulihkannya keadaan semula.Anak yang melakukan tindak pidana kesusilaan diselesaikan dengan hukum adat Bajo. Tujuan dari mediasi yang dilakukan oleh hukum adat Bajo ini adalah untuk mengembalikan kerugian yang dialami korban, sehingga hasil perbuatan yang dilakukan oleh pelaku dapat dipertanggung jawabkan.Penelitian ini merupakan penelitian lapangan atau sering disebut penelitian hukum empiris.Dengan menggunakan pendekatan yuridis sosiologis, analisis dalam penelitian ini menggunakan deskriptif kualitatif yaitu dengan cara mengambarkan secara keseluruhan keadaan yang akan diteliti di lapangan secara jelas, sehingga mencapai kejelasan dengan masalah yang akan dibahas. Hasil dari penelitian ini menunjukkan bahwa anak yang melakukan tindak pidanakesusilaan pada masyarakat adat Bajo dari tahun $2010 \mathrm{~s} / \mathrm{d}$ tahun 2013 sebanyak 41 orang anak yang melakukan tindak pidana kesusilaan, dan keseluruhan proses penyelesaiannya dilakukan secara adat.
\end{abstract}

Kata kunci: restorative justice, anak, tindak pidana kesusilaan, dan hukum adat bajo 


\section{Latar Belakang}

Anak ${ }^{1}$ membutuhkan adanya perlindungan hukum. Masalah perlindungan hukum bagi anak merupakan salah satu cara melindungi tunas bangsa di masa depan. Perlindungan hukum terhadap anak merupakan semua aturan hukum yang berlaku, terutama terhadap anak yang melakukan tindak pidana kesusilaan.Perlindungan ini perlu karena anak merupakan bagian masyarakat yang mempunyai keterbatasan secara fisik dan mentalnya.

Anak bukanlah untuk dihukum, melainkan harus diberikan bimbingan dan pembinaan, sehingga bisa tumbuh dan berkembang sebagai anak normal yang sehat dan cerdas seutuhnya. Anak merupakan calon generasi penerus bangsa yang masih dalam masa perkembangan fisik dan mental. Terkadang anak mengalami situasi sulityang membuatnya melakukan tindakan yang melanggar hukum. ${ }^{2}$ Walaupun demikian, anak yang melanggar hukum tidak layak untuk diberikan hukuman, apalagi dimasukkan dalam penjara. Oleh sebab itu, anak memerlukan perlindungan dan perawatan khusus. ${ }^{3}$
Isu perkembangan anak, menjadi salah satu bagian terpenting, karena negara sebagai tempat untuk melindungi setiap warganya harus memberikan jaminan utama terhadap perlindungan bagi anak. Seiring berkembangnya teknologi informasi yang sulit dibendung, ditambah lagi dengan iklim demokrasi yang menjamin kebebasan pers, maka berbagai macam isu sangatlah mudah untuk disampaikan ke hadapan publik. ${ }^{4}$

Kasus mengenai perkara anak selama ini menjadi perhatian yang sangat menarik bagi publik, di mana anak-anak yang seharusnya mendapatkan perlindungan bagi negara, akan tetapi kurangnya perhatian dari negara menjadikan anak sebagai pelaku kejahatan.

Penerapan sanksi pidana kepada pelaku kejahatan khususnya anak, dapat memberikan pencegahan kepada pelaku dan masyarakat untuk tidak berbuat kejahatan kembali. Tujuan ini terkadang mengalami kegagalan, karena justru pelaku kejahatan menjadi residivis dan masyarakat bertindak meniru melakukan kejahatan. Hal ini dikarenakan penerapan sanksi pidana tidak dapat melihat akar persoalan yang menjadi sebab timbulnya

1 Menurut Nicholas McBala dalam bukunya Marlina, Peradilan Pidana Anak di Indonesia Pengembangan Konsep Diversi dan Restorative Justice, Refika Aditama, Bandung, 2012, mengatakan anak yaitu periode di antara kelahiran dan permulaan kedewasaan. Masa ini merupakan masa perkembangan hidup, juga masa dalam keterbatasan kemampuan termasuk keterbatasan untuk membahayakan orang lain.

2 M. Nasir Djamil, Anak Bukan untuk Dihukum, Sinar Grafika, Jakarta, 2013, hlm. 1.

3 Pasal 1 angka 15 Undang-undang Nomor 23 Tahun 2002, Perlindungan Khusus adalah perlindungan yang diberikan kepada anak dalam situasi darurat, anak yang berhadapan dengan hukum, anak dari kelompok minoritas dan terisolasi, anak yang dieksploitasi secara ekonomi dan/atau seksual, anak yang diperdagangkan, anak yang menjadi korban penyalahgunaan narkotika, alcohol, psikotropika, dan zat adiktif lainnya (napza), anak korban penculikan, penjualan, perdagangan, anak korban kekerasan baik fisik dan/atau mental, anak yang menyandang cacat, dan anak korban perlakuan salah dan penelantaran. Lihat Undang-undang Nomor 23 Tahun 2002 tentang Perlindungan Anak.

4 M. Natsir Djamil, Op.cit., hlm. 1. 
perbuatan pidana. Oleh karena itu, dibutuhkan suatu pemikiran untuk melakukan pendekatan sosial di samping penerapan sanksi pidana.

Lahirnya Undang-undang Nomor 3 Tahun 1997 (selanjutnya disebut Undang-undang Pengadilan Anak) sebagai sarana penal, belum tentu bisa menyelesaikan permasalah terbesar anak-anak yang berhadapan dengan hukum. Undang-undang ini sudah tidak relevan lagi, baik dari aspek yuridis, sosiologis dan filosofis, karena undang-undang ini tidak memberikan solusi yang tepat bagi penanganan anak, sebagaimana yang telah ada pada Undangundang Nomor 23 Tahun 2002 (selanjutnya disebut Undang-undang Perlindungan Anak) sebagai anak yang berhadapan dengan hukum.

Anak yang berhadapan dengan hukum ${ }^{5}$ harus diarahkan untuk diselesaikan ke pengadilan, akibatnya adalah anak akan mendapatkan tekanan mental dan psikologi anak menjadi terganggu, sehingga mengganggu untuk tumbuh kembang anak. Model penanganan yang berlaku pada UndangUndang Nomor 3 Tahun 1997 (selanjutnya disebut Undang-Undang Pengadilan Anak), adalah sebagaimana penanganan perkara pada orang dewasa, dengan model retributive justice yaitu penghukuman sebagai pilihan yang utama atau pembalasan atas tindak pidana yang telah dilakukan. ${ }^{6}$

Proses penanganan anak yang berhadapan dengan hukum ${ }^{7}$ dapat menimbulkan permasalahan karena mereka harus ditangani secara hukum. Padahal kenyataannya, tidak jarang penanganan anak yang berkonflik dengan hukum tersebut, tidak dipisahkan dengan orang dewasa, seperti pemenjaraan yang tetap disatukan dengan orang dewasa. Akibatnya membuat anak berinteraksi dengan orang dewasa menjadi lebih sering dan akan membuat anak belajar dari proses interaksi itu.

Undang-undang Perlindungan Anak menyebutkan bahwa Pasal 64 ayat (1): Perlindungan khusus bagi anak yang berhadapan dengan hukum sebagaimana dimaksud dalam Pasal 59 meliputi anak yang berkonflik dengan hukum ${ }^{8}$ dan anak korban tindak pidana, ${ }^{9}$ merupakan kewajiban dan tanggung jawab pemerintah dan masyarakat. ${ }^{10}$

Anak haruslah ditangani secara berbeda dengan orang dewasa. Lahirnya Undang-

5 Pasal 1 angka 2 Undang-undang Nomor 11 Tahun 2012 tentang Sistem Peradilan Pidana Anak. Anak yang Berhadapan dengan Hukum adalah anak yang berkonflik dengan hukum, anak yang menjadi korban tindak pidana, dan anak yang menjadi sanksi tindak pidana.

6 M. Nasir Djamil, Op.cit., hlm. 4.

7 Dari tingkat penyelidikan, penyidikan, penuntutan, pemeriksaan di Pengadilan hingga sampai penempatan di Lembaga Pemasyarakatan Anak, anak yang berhadapan dengan hukum atau anak yang berkonflik dengan hukum ditangani layaknya seorang penjahat, adanya peras pengakuan, dan sebagainya. Sehingga akan mengganggu pertumbuhan mental psikologis anak.

8 Pasal 1 angka 2 Undang-undang Nomor 11 Tahun 2012. Anak yang Berkonflik dengan Hukum yang selanjutnya disebut Anak adalah anak yang telah berumur 12 (dua belas) tahun, tetapi belum berumur 18 (delapan belas) tahun yang diduga melakukan tindak pidana. Op.cit.

9 Pasal 1 angka 4, Anak yang menjadi Korban Tindak Pidana yang selanjutnya disebut Anak Korban adalah anak yang berumur 18 (delapan belas) tahun yang mengalami penderitaan fisik, mental, dan/atau kerugian ekonomi yang disebabkan oleh tindak pidana. Ibid.

10 Undang-undang Nomor 23 Tahun 2002, Op.cit. 
undang Nomor 11 Tahun 2012 (selanjutnya disebut Undang-undang Sistem Peradilan Pidana Anak), atas perubahan Undang-undang Pengadilan Anak, setidaknya memberikan perubahan hukum terhadap anak-anak yang berkonflik dengan hukum.

Undang-undang Sistem Peradilan Anak ini mengedepankan model restorative justice, yaitu pemulihan ke kondisi semula, dan pemidanaan merupakan jalan akhir, sehingga perlu didahulukan jalan lain di luar pengadilan. Salah satunya yaitu dengan cara diversi, yakni pengalihan penyelesaian perkara anak dari proses peradilan pidana ke proses di luar peradilan pidana. Diversi merupakan jalan yang paling tepat dalam Undang-Undang Sistem Peradilan Pidana Anak ini, agar anak tidak dibawa ke pengadilan. Dalam hal untuk menerapkan diversi, diskresi dari pihak kepolisian sangatlah penting.

Fungsi Kepolisian adalah salah satu fungsi pemerintahan negara di bidang pemeliharaan keamanan dan ketertiban masyarakat, penegakan hukum, perlindungan, pengayoman, dan pelayanan kepada masyarakat. Dalam fungsi demikian, Lypsky mengatakan bahwa polisi sebagai salah satu bagian dari street level bureaucracy atau pelaksana birokrasi pemerintahan di tingkat jalanan yang langsung berhadapan dengan masyarakat. Halinikarena Polisi sesungguhnya menjalankan fungsi pemerintahan, seperti institusi pemerintah yang lain, khususnya untuk mewujudkan keamanan dalam negeri, yang meliputi terpeliharanya keamanan dan ketertiban masyarakat, tertib dan tegaknya hukum, terselenggaranya perlindungan, pengayoman, dan pelayanan kepada masyarakat dengan menjunjung tinggi hukum dan hak asasi manusia. ${ }^{11}$

Undang-undang Republik Indonesia Nomor 2 Tahun 2002 (selanjutnya disebut Undang-undang Kepolisian), Pasal 19 menyebutkan, bahwa: ${ }^{12}$

(1) Dalam melaksanakan tugas dan wewenangnya, Pejabat Kepolisian Republik Indonesia dalam melaksanakan tugas dan wewenangnya senantiasa bertindak berdasarkan norma hukum dan menggindahkan norma agama, kesopanan, kesusilaan, serta menjunjung tinggi hak asasi manusia.

(2) Dalam melaksanakan tugas dan wewenang sebagaimana yang dimaksud dalam ayat(1), Kepolisian Negara Republik Indonesia mengutamakan tindakan pencegahan.

Penegakkan hukum amat ditentukan oleh aspek moral dan etika dari aparat penegak hukum itu sendiri. Aspek moral dan etika dalam penegakkan hukum pidana merupakan suatu hal yang berkaitan dengan penegakkan hukum pidana dalam sistem peradilan pidana. Penegakkan hukum terhadap aturan-aturan hukum tidak berbatas pada tindakan dengan

11 I Nyoman Nurjaya, Artikel (Kewenangan Diskresi dan Diversi Polisi dalam Tugas Penegakan Hukum Pidana), makalah dipresentasikan dalam Seminar Kepolisian dengan Tema "Penegakan Hukum Selektif oleh Polri: Keniscayaan Yang Tidak Diakui, Legalitas dan Relevansinya dengan Kepastian Hukum”, diselenggarakan dalam rangka Hari Ulang Tahun Bhayangkara Ke 67 Tahun 2013 oleh Kepolisian Resort Blitar Kota, 5 Juni 2013, Gedung Kusuma Wicitra Kota Blitar, hlm. 1.

12 Undang-undang Republik Indonesia Nomor 2 Tahun 2002 tentang Kepolisian. 
menghukum dan memasukkan ke dalam penjara sebanyak-banyaknya. Namun yang lebih substansial adalah bagaimana upaya penegak hukum dapat membimbing warga masyarakat agar tidak melakukan perbuatan melanggar hukum. ${ }^{13}$

Bekerjanya proses peradilan pidana pada dasarnya merupakan suatu rangkaian keputusan-keputusan mengenai suatu tindak pidana dari petugas yang berwenang dalam kerangka interrelasi antara petugas dengan sub-sub sistem peradilan pidana. Pendekatakan sistemik ini mensyaratkan perlunya upayaupaya yang mendukung bekerjanya sistem ini, yaitu: ${ }^{14}$

a. Meningkatkan efektivitas sistem penanggulangan kejahatan;

b. Mengembangkan koordinasi antara berbagai komponen peradilan pidana;

c. Mengawasi atau mengendalikan penggunaan kekuasaan oleh penegak hukum.

Penanggulangan kejahatan mengenai jalur "penal" menyangkut bekerjanya fungsi aparatur penegak hukum sistem peradilan pidana yang terdiri dari kepolisian, kejaksaan, pengadilan, dan lembaga pemasyarakatan. Penanggulangan lewat jalur "penal" lebih menitik beratkan pada sifat "repressive" (penindasan/pemberantasan/penumpasan) sesudah kejahatan terjadi, sedangkan jalur "nonpenal" lebih menitik beratkan pada sifat "preventive" (pencegahan/penangkalan/ pengendalian) sebelum kejahatan terjadi. Jalur "nonpenal" merupakan jalur penanggulangan dengan cara peningkatan nilai keagamaan, penyuluhan melalui pemuka masyarakat, dan kegiatan lainnya. Persoalan kejahatan tidak hanya diarahkan pada penyelesaian melalui proses peradilan, tetapi bisa melalui nonperadilan. ${ }^{15}$

Patut disadari bahwa penggunaan sanksi pidana sebagai alat penegakkan hukum ibarat pedang yang tajam pada kedua sisinya. Sanksi pidana disatu sisi merupakan penjamin utama terhadap hak-hak individu. Akan tetapi sanksi pidana pada sisi yang lainnya juga merupakan ancaman terbesar terhadap kemerdekaan dan hak-hak asasi manusia. Penggunaan sanksi pidana yang manusiawi dan tidak memihak akan menjamin perlindungan itu, tetapi penggunaan yang diskriminatif dan bersifat paksaan merupakan suatu ancaman tersendiri.

Menurut G. Pieter Hoefnagels, ${ }^{16}$ keterlibatan masyarakat dalam kebijakan penanggulangan kejahatan sangat penting, karena kebijakan penanggulangan kejahatan merupakan usaha yang rasional dari masyarakat sebagai reaksi terhadap kejahatan. Selanjutnya dikatakan bahwa kebijakan penanggulangan kejahatan merupakan ilmu untuk menanggulangi kejahatan. Oleh karena

13 Siswanto Sunarso, Viktimologi dalam Sistem Peradilan Pidana, Sinar Grafika, Jakarta, 2012, hlm. 83.

14 Takdir Rahmadi, Mediasi Penyelesaian Sengketa Melalui Pendekatan Mufakat, RajaGrafindo Persada, Jakarta, 2010, hlm. 26.

15 Marlina, Peradilan Pidana Anak di Indonesia, Pengembangan Konsep Diversi dan Restorative Justice, Refika Aditama, Bandung, 2012, hlm. 16.

16 Ibid., hlm. 15. 
itu, kebijakan penanggulangan kejahatan dilakukan dengan perencanaan yang rasional dan menyeluruh sebagai respon terhadap kejahatan. Kebijakan yang dilakukan termasuk bagaimana mendesain tingkah laku manusia yang dapat dianggap sebagai kejahatan.

Menurut G. Pieter Hoefnagels upaya penanggulangan kejahatan dapat ditempuh dengan beberapa cara, yaitu: ${ }^{17}$

1. Penerapan hukum pidana (criminal law application)

2. Pencegahan tanpa pidana (prevention without punishment)

3. Mempengaruhi pandangan masyarakat mengenai kejahatan dan pemidanaan lewat media massa (influencing views of society on crime and punishment).

Pendekatan terhadap upaya penanggulangan kejahatan harus dilakukan secara integral karena persoalan kejahatan merupakan persoalan kemanusiaan dan sosial.Pendekatan hanya melalui penerapan hukum pidana semata-mata tidaklah tepat, karena penerapan hukum pidana mempunyai keterbatasan. Berikut adalah beberapa faktor penyebab terjadinya kejahatan: ${ }^{18}$

1. Dari sisi hakikat terjadinya kejahatan. Kejahatan sebagai masalah sosial dan kemanusiaan tentu faktor penyebab lahirnya kejahatan cukup kompleks. Banyaknya faktor penyebab kejahatan tidak mampu dijangkau oleh hukum pidana. Ketidakmampuan hukum pidana menganalisa penyebab lahirnya kejahatan menyebabkan hukum pidana membutuhkan bantuan dari disiplin ilmu yang lain. Oleh karena itu, dalam membahas upaya penanggulangan kejahatan, hukum pidana dipadukan dengan pendekatan sosial.

2. Keterbatasan hukum pidana terlihat dari hakikat berfungsinya hukum pidana itu sendiri. Penggunaan hukum pidana hakikatnya hanya obat sesaat sebagai penanggulangan gejala semata dan bukan alat penyelesaian yang tuntas dengan menghilangkan sumber penyebab penyakitnya. Artinya hukum pidana tidak memberikan efek pencegahan sebelum kejahatan itu terjadi, sehingga hukum pidana tidak mampu menjangkau akar kejahatan yang berada di tengah masyarakat.

Sanksi hukum pidana yang digunakan selama ini bukanlah obat (remidium) untuk memberantas sumber penyakit (kejahatan), melainkan hanya sekedar mengatasi gejala atau akibat penyakit. Artinya sanksi hukum pidana bukanlah suatu pengobatan yang menyeluruh, melainkan hanya sekedar pengobatan yang bersifat sementara.

Kejahatan kesusilaan pada umumnya menimbulkan kekwatiran/kecemasan khususnya orang tua terhadap anak wanita karena selain dapat mengancam keselamatan anak-anak wanita (misalnya perkosaan dan perbuatan cabul) dapat pula mempengaruhi proses pertumbuhan kearah kedewasaan seksual lebih dini. Delik ini paling banyak menimbulkan kesulitan dalam penyelesaian baik pada tahap penyidikan, penuntutan maupun pada tahap pengambilan keputusan. Selain kesulitan dalam batasan juga kesulitan pembuktian misalnya perkosaan atau perbuatan cabul yang pada umumnya dilakukan tanpa kehadiran orang lain. 
Berkaitan dengan tindak pidana Pidana Anak Pasal 5 ayat (1) mengutamakan kesusilaan, bahwa sebagai makhluk sosial pendekatan keadilan restoratif. Restorative tindak pidana kesusilaan akan terjadi dan justice merupakan penyelesaian perkara menimpa kepada setiap orang yang tidak tindak pidana dengan melibatkan pelaku, memandang latar belakang pendidikan, korban, keluarga/korban, dan pihak lain pekerjaan, dan jabatan disebabkan karena lemahnya kontrol diri, lemahnya iman sesuai dengan agama yang dianutnya. Hal ini bisa terjadi disebabkan dengan latar belakang yang berbeda-beda, terutama pada anak dalam masa pencarian jati diri, mereka ingin diakui secara kedewasaannya sehingga membuat anak terjebak dalam perbuatan yang melanggar hukum.

Terhadap delik ini, Mr. J. M. van Bemmelen mengutarakan antara lain sebagai berikut: 19

"Delik terhadap kesusilaan tidak hanya memuat berbagai kejahatan seksual, akan tetapijuga ada beberapa delik yang tidak ada sangkut pautnya dengan seksualitas: memberi minuman yang memabukkan kepada orang atau anak di bawah enam belas tahun, menyerahkan atau membiarkan anak yang ada di bawah kekuasaannya kepada orang lain, padahal dapat diketahui bahwa anak itu akan dipakai untuk atau pada waktu mengemis, penganiyayaan binatang, selanjutnya memuat abortus provocatus."

Anak yang melakukan tindak pidana berdasarkan Undang-undang Sistem Peradilan yang terkait untuk bersama-sama mencari penyelesaian yang adil dengan menekankan pemulihan kembali pada keadaan semula, dan bukan pembalasan. ${ }^{20}$

Pendapat G. Pieter Hoefnagels ${ }^{21}$ secara tidak langsung menunjukkan bahwa jalur penal atau jalur pidana bukan merupakan satusatunya upaya penanggulangan kejahatan G. Pieter Hoefnagels mengakui jalur nonpenal dapat dilakukan dalam upaya penanggulangan kejahatan. Konsep diversi dan restorative justice $^{22}$ merupakan dua konsep penyelesaian tindak pidana yang memberikan perlindungan terhadap anak. Kedua konsep tersebut dalam penyelesaiannya melibatkan persetujuan korban, pelaku, dan masyarakat.

Walaupun pada umumnya penyelesaian sengketa di luar pengadilan hanya ada dalam sengketa perdata, namun dalam praktek sering juga kasus pidana diselesaikan di luar pengadilan melalui berbagai diskresi ${ }^{23}$ aparat penegak hukum atau melalui mekanisme musyawarah/perdamaian atau lembaga permaafan yang ada di dalam masyarakat. Praktek penyelesaian perkara pidana di luar pengadilan selama ini tidak ada

19 P.A.F. Lamintang, Dasar-dasar Hukum Pidana Indonesia, Citra Aditya Bakti, Bandung, 1997, hlm. 31.

20 Undang-undang Nomor 11 Tahun 2012, Loc.cit.

21 Marlina, Loc.cit., hlm. 16.

22 Menurut penulis, konsep diversi dan restorative justice ini, merupakan bentuk alternatif penyelesaian tindak pidana yang diarahkan kepada penyelesaian secara informal dengan melibatkan semua pihak yang terkait dalam tindak pidana yang terjadi. 
landasan hukum formalnya, sehingga sering terjadi kasus yang secara informal telah ada penyelesaian damai, namun tetap saja diproses di pengadilan sesuai hukum yang berlaku. ${ }^{24}$

Upaya untuk menurunkan angka kriminalitas, sistem peradilan pidana saja tidak begitu cukup. Tetapi dengan menggunakan cara-cara tradisional misalnya hukum adat yang ada pada daerah masing-masing bisa dikatakan mampu menurunkan angka kriminalistas dibandingkan dimasukkan dalam sebuah sistem hukum. Hukum adat bercorak tradisional, artinya bersifat turuntemurun, dari zaman nenek moyang hingga ke anak cucu sekarang ini yang keadaanya masih tetap berlaku dan dipertahankan oleh masyarakat adat yang bersangkutan. Beberapa corak yang melekat dalam hukum adat yang dapat dijadikan sumber pengenalan hukum adat dapat disebutkan, yaitu corak yang tradisional, keagamaan, kebersamaan, konkret dan visual, terbuka dan sederhana, dapat berubah dan menyesuaikan, tidak dikodifikasi, musyawarah dan mufakat.

Begitu pula dengan suatu sistem hukum adat, menyebut suatu masyarakat sebagai masyarakat tradisional tidak lain hendak memberikan arti tentang masyarakat yang kuat memegang tradisi atau yang dikenal dengan adat (adat kebiasaan) yang diwariskan dari leluhurnya. ${ }^{25}$ Identitas hukumnya tumbuh dengan identitas masyarakat yang membentuknya. Oleh karena itu hukum adat merupakan suatu sistem hukum yang dibentuk berdasarkan sifat, pandangan hidup dan cara berfikir masyarakat bangsa Indonesia. Kenyataan ini pernah ditegaskan oleh Soediman Kartohadiprodjo ${ }^{26}$ dalam bukunya Dewi Wulansari yang mengatakan: "hukum adat itu bukan hukum adat karena bentuknya tidak tertulis, melainkan hukum adat adalah hukum adat karena tersusun dengan dasar pikiran yang tertentu, prinsipil berbeda dari dasar pikiran hukum barat".

Masyarakat hukum adat menggunakan penyelesaian secara kekeluargaan. Mediasi di luar pengadilan merupakan proses peyelesaian sengketa secara damai yang biasa digunakan masyarakat sehari-hari ditengahi oleh pihak ketiga yaitu tetua adat, pemimpin agama, atau tokoh masyarakat lainnya. ${ }^{27}$ Oleh karena itu, hukum adat merupakan aspek dari kehidupan dan kebudayaan masyarakat Indonesia yang juga menjadi saripati dari kebutuhan hidup, cara hidup, dan pandangan hidup masyarakat bangsa Indonesia yang berbeda dengan alam

23 Marlina, Log.cit., menyebutkan bahwa diskresi merupakan wewenang petugas kepolisian untuk mengambil tindakan meneruskan perkara atau menghentikan perkara sesuai dengan kebijakan yang dimilikinya. Proses diskresi berlangsung secara spontan yang timbul dalam diri pribadi seorang aparat penegak hukum tanpa direncanakan terlebih dahulu. Tindakan diskresi merupakan tindakan keseharian yang dilakukan oleh petugas polisi, jaksa, hakim, penasehat hukum, psikiater, lembaga pemasyarakatan, petugas imigrasi, dan komponen lainnya untuk menggelakkan dan mendorong seseorang ke dalam atau ke luar dari sistem peradilan pidana dan mengarahkannya ke lembaga pengawasan lain yang dianggap paling tepat.

24 Barda Nawawi, Mediasi Penal Penyelesaian Perkara di Luar Pengadilan, Pustaka Magister, Semarang, 2010, hlm. 4.

25 Romli Atmasasmita, Teori dan Kapita Selekta Krominologi, Refika Aditama, Bandung, 2010, hlm. 133.

26 Dewi Wulansari, Hukum Adat Indonesia, Suatu Pengantar, Refika Aditama, Bandung, 2012, hlm. 22. 
pikir barat yang melahirkan sistem hukum dengan dasar alam pikiran di atas.

Pendekatan konsensus atau mufakat dalam proses mediasi mengandung pengertian, bahwa segala sesuatu yang dihasilkan dalam proses mediasi harus merupakan hasil kesepakatan atau persetujuan para pihak. Mediasi ${ }^{28}$ dapat ditempuh oleh para pihak yang terdiri atas dua pihak yang bersengketa maupun oleh lebih dari dua pihak. Penyelesaiannya dapat diselesaikan apabila semua pihak yang bersengketa dapat menerima penyelesaian itu. ${ }^{29}$

Hukum adat Indonesia sebagai wadah dari institusi peradilan adat juga memiliki konsep yang dapat digambarkan sebagai akar keadilan restoratif. Di Indonesia, karakteristik dari hukum adat di tiap daerah pada umumnya amat mendukung penerapan keadilan restoratif. Hal ini dapat dilihat dari ciri-ciri umum hukum adat Indonesia, pandangan terhadap pelanggaran adat/delik adat serta model dan cara penyelesaian yang ditawarkan.

Pada masyarakat Bajo, lebih mengutamakan hukum adat dalam penyelesaian perkara anak. Perbedaan kesusilaan yang dilakukan oleh anak sebagai pelaku tindak pidana kesusilaan dalam hukum adat Bajo ini, sepanjang bujang dengan bujang hanya melibatkan ketua adat sebagai mediatornya, apabila salah satu terikat perkawinan, maka si pelaku diberikan sanksi adat, yaitu di Bua (diasingkan) dari desa. ${ }^{30}$

Anak yang melakukan tindak pidana kesusilaan pada masyarakat Adat Bajo ini dari tahun ke tahun semakin meningkat, tercatat sebanyak 41 kasus tindak pidana kesusilaan yang dilakukan oleh anak, dengan rincian sebagai berikut: pada tahun 2010 sebanyak 9 kasus, 2011 sebanyak 7 kasus, 2012 sebanyak 10 kasus dan 2013 sebanyak 15 kasus. Anakanak yang sudah dikategorikan melakukan tindak pidana kesusilaan oleh adat ini berawal dari pacaran antara bujang sama bujang dan diketahui oleh masyarakat atau orang tuanya, sehingga mengakibatkan kekhawatiran dan malu dari pihak keluarga, dan mencemarkan tata tertib yang berada di desa tersebut. ${ }^{31}$

Anak yang melakukan tindak pidana kesusilaan tidak langsung dilimpahkan ke pengadilan, tetapi diselesaikan dengan hukum adat Bajo itu sendiri, dengan jalan mediasi. Proses yang dilakukan oleh suku Bajo ini dengan melibatkan pelaku, korban, dan orang tua yang dipimpin oleh seorang Ketua Adat yang disebut dengan Punggawa

27 Fatahillah Syukur, Mediasi Yudisial di Indonesia, Mandar Maju, Bandung, 2012, hlm. 1.

28 Agustinus Pohan, Topo Santoso, dan Martin Moerings, Hukum Pidana Dalam Perspektif, menyebutkan bahwa mediasi penal sendiri merupakan salah satu bentuk alternatif penyelesaian sengketa di Luar Pengadilan (dikenal dengan istilah ADR atau Alternative Dispute Resolution). Pendapat lain dari Fatahillah Syukur dalam bukunya juga menyebutkan bahwa mediasi merupakan metode penyelesaian sengketa yang berkembang pesat, penggunaan mediasi tidak hanya dilakukan di luar pengadilanoleh lembaga swasta dan swadaya masyarakat, tetapi juga terintegrasi dalam sistem peradilan, dalam hal ini, tidak hanya memediasi perkara perdata, akan tetapi memediasi perkara pidana, mencakup tindak pidana ringan yaitu pencurian, maupun tindak pidana berat seperti pembunuhan, sesuai dengan adat istiadat daerah masing-masing.

29 Takdir Rahmadi, Log.cit., hlm. 13.

30 Wawancara dengan Bapak Baharudin Jatung, Tokoh Agama masyarakat Adat Bajo, 27 Agustus 2013. 
dan disaksikan oleh masyarakat adat Bajo itu sendiri. Orang-orang ini dilibatkan dengan maksud, karena mereka juga terkena dampak dan imbas dalam berbagai bentuk akibat dari suatu kejahatan yang dilakukan oleh pelaku. Mereka juga dapat berpartisipasi dalam bentuk menyampaikan dan menjelaskan hasil kesepakatan yang harus dilaksanakan oleh kedua belah pihak yakni pelaku dan korban. ${ }^{32}$

Tujuan dari mediasi yang dilakukan oleh hukum adat Bajo ini adalah dengan mendapatkan kejelasan dari peristiwa yang terjadi dengan memberi semangat kepada pelaku, mengembalikan kerugian yang dialami korban, melakukan interogasi kepada kedua belah pihak, sehingga hasil perbuatan yang dilakukan oleh pelaku dapat dipertanggung jawabkan.

Sasarannya untuk memberikan kesempatan kepada korban untuk terlibat secara langsung dalam suatu diskusi yang dilakukan oleh hukum adat Bajo itu, sehingga terciptanya suatu keputusan mengenai pelanggaran kesusilaan yang terjadi terhadap pelaku, dan meminta penjelasan dari pelaku terhadap pelanggaran kesusilaan yang terjadi. Meningkatkan kepedulian pelaku atas akibat perbuatannya kepada orang lain serta memberikan kesempatan kepada pelaku untuk bertanggung jawab penuh atas perbuatannya. Selain itu, bagi pihak keluarga baik keluarga pelaku dan keluarga korban untuk dapat sama- sama menentukan sanksi bagi pelaku, dan membimbing pelaku selama proses mediasi dilaksanakan. Terakhir adalah memberikan kesempatan korban dan pelaku untuk saling berhubungan dalam memperkuat kembali tatanan masyarakat adat yang sempat terpecah karena telah terjadi pelanggaran kesusilaan. ${ }^{33}$

Pandangan hukum adat, tidak ada ketentuan keberlakuannya disertai dengan syarat yang menjamin ketaatannya dengan jalan menggunakan paksaan. Sanksi adat tidak sama pengertiannya dengan pemidanaan, suatu penerapan sanksi adat adalah suatu upaya, untuk mengembalikan langkah yang berada di luar garis kosmos demi tidak terganggunya ketertiban kosmos. Jadi sanksi adat merupakan usaha untuk mengembalikan keseimbangan yang terganggu.

Dari latar belakang di atas, sehingga rumusan masalah yang diangkat sebagai berikut:

1. Bagaimana Bentuk Penyelesaian Hukum Adat Bajo Terkait Dengan Tindak Pidana Kesusilaan Yang Dilakukan Oleh Anak?

2. Bagaimanakah Penggunaan Hukum Adat Bajo Untuk Menyelesaikan Perkara Anak Yang Melakukan Tindak Pidana Kesusilaan Yang Mencerminkan Keadilan Restoratif?

Jenis penelitian ini adalah penelitian lapangan atau sering disebut penelitian Hukum Empiris, yaitu penelitian yang 
melihat langsung kenyataan dilapangan, jenis penelitian ini memiliki sifat dan karakter yang menampakkan kesenjangan antarahukum yang berlaku dengan kenyataan masyarakat adat Bajo dengan melihat permasalahan perkara anak sebagai pelaku tindak pidana, dengan menggunakan pendekatan yuridis sosiologis, yaitu pendekatan ini dilakukan dengan melihat kesenjangan antara norma dengan hukum adat yang berlaku di Suku Bajo dan analisis dalam penelitian ini menggunakan deskriptif kualitatif yaitu dengan cara mengambarkan secara keseluruhan keadaan dari objek yang akan diteliti di lapangan secara jelas, sehingga mencapai kejelasan dengan masalah yang akan dibahas.

\section{Pembahasan}

\section{A. Gambaran Umum Lokasi}

Pada dasarnya masyarakat Bajo merupakan sekumpulan masyarakat adat yang menaungi desa Jaya Bhakti, dalam pasal $18 \mathrm{~B}$ ayat 2 Undang-Undang Dasar Negara Republik Indonesia menyebutkan bahwa: "Negara mengakui dan menghormati kesatuankesatuan masyarakat hukum adat beserta hak-hak tradisionalnya sepanjang masih hidup sesuai dengan perkembangan masyarakat dan prinsip Negara Kesatuan Republik Indonesia, yang diatur dalam undang-undang".

Pada tahun 1825 sekelompok suku Sama (Bajo) telah ada di sekitar Pagimana. Mereka berpusat di Bungging (muara kuala Pagimana) dan sering berpindah-pindah menjelajahi hingga ke Teluk Tomini, Moutong, Popayato, Ampibabo, dan sebagian menetap di sana. Kemudian, pada tahun 1908 masyarakat ini kembali lagi berkumpul di Pagimana dan kembali bermasyarakat yang diberi nama kampung Bajo.

Berikut disajikan bagan 1 tentang struktur kepemimpinan masyarakat adat Bajo sejak tahun 1990 sampai sekarang: ${ }^{34}$

Pada saat terjadi tindak pidana kesusilaan yang dilakukan oleh anak, pelaku dihadapkan ke Ketua Adat dalam hal ini Punggawa, oleh ketua adat berkoordinasi dengan wakil ketua adat serta tokoh masyarakat dan tokoh agama, akan merundingkan sanksi apa yang diberikan kepada pelaku.

Sebagaimana yang penulis kemukakan di bawah ini, kepemimpinan untuk mengemban sebagai ketua adat Bajo tidak menggenal batasan periode, akan tetapi mempunyai persyaratan-persyaratan tertentu, diantaranya:

a. Kondisi fisik masih sehat, artinya masih bisa melakukan aktifitas.

b. Belum pikun.

Suku Bajo ini akhirnya bertempat tinggal di desa Jaya Bhakti. Desa ini dianugrahkan oleh pemerintah daerah Tinggkat II Banggai, desa ini dipimpin oleh Kepala Desa Hakim Minggu, tepatnya pada tanggal 19 Mei 1965, saat ini desa dipimpin oleh Ndali Minggu sebagai Ketua Adat. 


\section{Bagan 1. Struktur Kepemimpinan Masyarakat Adat Bajo Desa Jaya Bhakti, Sulawesi}

Tengah

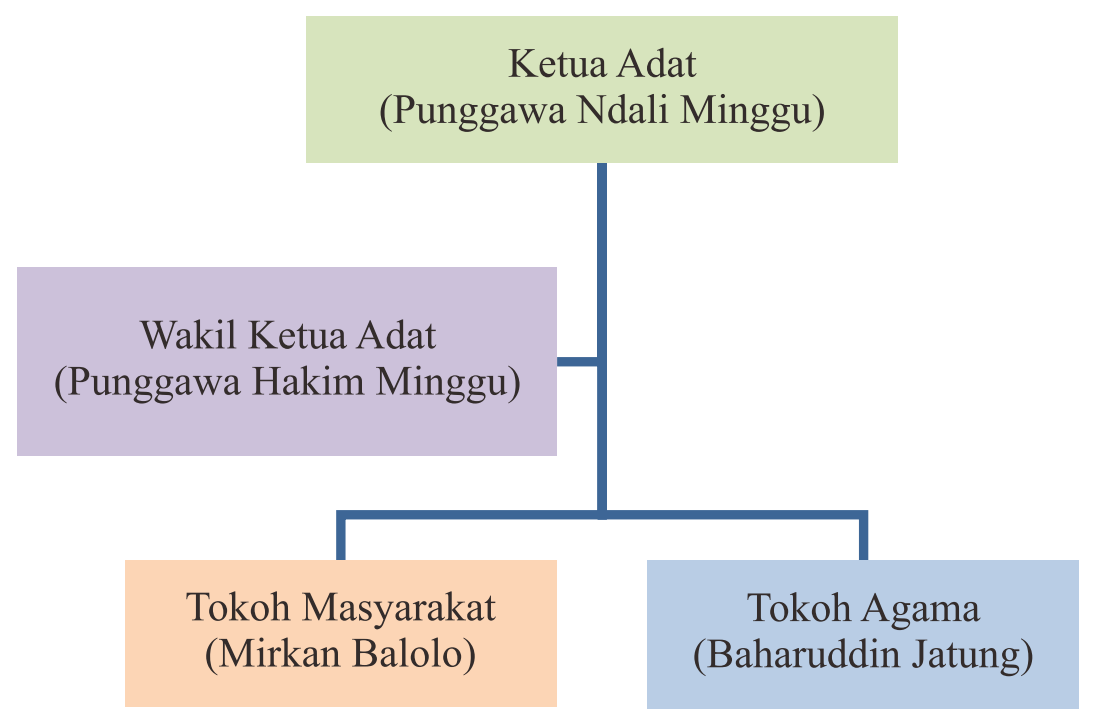

Sumber: Data Primer, diolah, 2014

Sebelah Utara desa ini adalah Laut Tongkonunu yang terletak di depan Kecamatan Pagimana, kurang lebih 500 meter dan dipisahkan oleh Teluk Tongkonunu, batas ke Barat adalah Tanjung Api, dan sekarang sudah menjadi sunggai Bilinggara ke Selatan berbatas dengan Tegong Teong (Pulau Teong), ke Timur Laut berbatas dengan Teluk Tomini atau dikatakan dengan Teluk Siuna, yang keseluruhannya terletak pada kecamatan Pagimana, Kabupaten Luwuk Banggai, Sulawesi Tengah.

Secara administratif desa Jaya Bhakti terdiri atas 5 dusun, jumlah penduduk desa Jaya Bhakti terdiri dari wanita 7.938 jiwa, pria 6.592 jiwa, anak-anak 3.502 jiwa, balita 2.300 jiwa, dan lansia 700 jiwa. Secara keseluruhan desa Jaya Bhakti menganut 100\% agama Islam, dengan pekerjaan rata-rata sebagai nelayan.
Berikut jumlah penduduk masyarakat adat Bajo di desa Jaya Bhakti, Sulawesi tengah:

Jumlah kepala keluarga di desa Jaya Bhakti ini adalah 1.470 kepala keluarga, dengan jumlah penduduk yaitu 21.032 jiwa, panjang desa $1.200 \mathrm{M}$, lebar kurang lebih 300 M. Desa Jaya Bhakti ini dapat dikatakan desa yang terpadat, karena 1 jiwa hanya mendapat tanah yang berukuran $5 \times 7$ meter, dan sudah termasuk semua fasilitas yang ada, seperti jalan raya.

\section{B. Bentuk Penyelesaian Hukum Adat} Bajo terkait dengan Tindak Pidana Kesusilaan yang Dilakukan oleh Anak

Hukum adat pada dasarnya merupakan hukum yang tidak tertulis, maka elastisitas dari eksistensi hukum adat dapat diandalkan. Sedangkan hukum Eropa yang pada umumnya merupakan hukum yang terkodifikasi dan 
Tabel 1. Jumlah Penduduk Masyarakat Adat Bajo di Desa Jaya Bhakti, Sulawesi Tengah

\begin{tabular}{|c|c|c|c|}
\hline NO. & Dusun & $\begin{array}{c}\text { Jumlah Kepala Keluarga } \\
\text { (KK) }\end{array}$ & Jumlah Penduduk \\
\hline 1. & Dusun 1 & 294 & 3.528 \\
\hline 2. & Dusun 2 & 315 & 4.410 \\
\hline 3. & Dusun 3 & 412 & 6.592 \\
\hline 4. & Dusun 4 & 233 & 3.262 \\
\hline 5. & Dusun 5 & 216 & 3.240 \\
\hline T O T A L & & $\mathbf{1 . 4 7 0}$ KK & $\mathbf{2 1 . 0 3 2}$ Jiwa \\
\hline
\end{tabular}

Sumber: Data Primer, diolah, 2014

tertulis, maka tidak bisa dihindarkan dari kendala kekakuan. Hal ini sudah menjadi konsekuensi logisnya, pada saat yang bersamaan merupakan keunggulan dari hukum adat untuk eksis dalam masyarakat dengan penampilan yang selalu relevan dan responsif.

Hukum adat pada hakikatnya merupakan hukum kebiasaan, artinya kebiasaankebiasaan yang mempunyai akibat hukum. Berbeda dengan kebiasaan belaka, kebiasaan yang merupakan hukum adat adalah perbuatan yang diulang-ulang dalam bentuk yang sama. Hukum adat terutama hukum yang mengatur tingkah laku manusia, dalam hubungannya satu dengan yang lain, baik yang merupakan keseluruhan kelaziman, kebiasaan dan kesusilaan yang benar-benar hidup di masyarakat adat karena dianut dan dipertahankan oleh anggota-anggota masyarakat itu maupun yang merupakan keseluruhan pengaturan yang mengenai sanksi atas pelanggaran dan yang ditetapkan dalam keputusan-keputusan para penguasa adat atau mereka yang mempunyai kewibawaan dan berkuasa member keputusan dalam masyarakat adat itu.

Hukum adat delik (adatrecht delicten) atau hukum pidana adat atau hukum pelanggaran adat ialah aturan-aturan hukum adat yang mengatur peristiwa atau perbuatan kesalahan yang berakibat terganggunya keseimbangan masyarakat sehingga perlu diselesaikan (dihukum) agar keseimbangan masyarakat tidak terganggu. Menurut Barend Ter Haar. B.Zn, yang dimaksud delik adat adalah delik (pelanggaran) itu juga adalah setiap gangguan dari suatu pihak terhadap keseimbangan dimana setiap pelanggaran itu dari satu pihak atau dari sekelompok orang berwujud atau tidak berwujud berakibat menimbulkan reaksi (yang besar kecilnya menurut ketentuan adat) suatu reaksi adat, dan dikarenakan adanya reaksi adat itu maka keseimbangan harus dapat dipulihkan kembali (dengan pembayaran uang atau barang). ${ }^{35}$

Fenomena permasalahan lembaga penjara pada dasarnya telah menjadi masalah klasik yang menjadi sorotan sejak lama bukan hanya di Indonesia, tetapi juga dibanyak negara. 
Tabel 2. Tindak Pidana Kesusilaan yang Dilakukan oleh Anak Pada Masyarakat Adat Bajo Tahun 2010 s/d 2013

\begin{tabular}{|c|r|r|r|r|}
\hline \multirow{2}{*}{ Tahun } & \multicolumn{4}{|c|}{ Terjadi Kasus } \\
\cline { 2 - 5 } & \multicolumn{2}{|c|}{2010} & \multicolumn{1}{c|}{2011} & \multicolumn{1}{c|}{2013} \\
\hline Tindak Pidana Kesusilaan & 9 & 7 & 10 & 15 \\
\hline
\end{tabular}

Sumber: Data Primer, diolah, 2014

Penjara pada masa lalu kerap digambarkan sebagai tempat dimana proses dehumanisasi berlangsung. Pada masyarakat adat, sanksi adat yang diberikan hanyalah mengembalikan keseimbangan yang terganggu, dan keluarga ikut menanggung akibat dari perbuatannya tersebut, sementara dalam sistem peradilan pidana, pertanggung jawaban pidana lebih dititik beratkan pada perseorangan.

Pada masyarakat adat Bajo, anak yang melakukan tindak pidana kesusilaan dari tahun ke tahun semakin meningkat, dapat dilihat pada tabel berikut ini:

Penjelasan terhadap Tabel 2 di atas adalah tindak pidana yang dilakukan oleh anak dalam masyarakat adat Bajo dari tahun ke tahun semakin meningkat, pada Tahun 2010 sebanyak 9 kasus, kemudian mengalami penurunan pada Tahun 2011 sebanyak 7 kasus, dan mengalami kenaikan lagi pada Tahun 2012 sebanyak 10 kasus dan pada Tahun 2013 sebanyak 15 kasus. Peningkatan tindak pidana kesusilaan yang dilakukan oleh anak, hal ini dikarenakan globalisasi yang semakin meluas, sehingga dapat mengakses video porno dengan mudahnya.
Menurut ketua adat Bajo yaitu Bapak Ndali Minggu, beliau mengatakan bahwa meningkatnya kasus kesusilaan yang terjadi di kalangan remaja, pada awalnya diakibatkan oleh pengenalan (pacaran) yang melampaui batas oleh anak-anak suku Bajo itu, kemudian akses media massa yang masuk begitu cepatnya dalam masyarakat Bajo, dengan adanya pengaruh dari media massa ini juga mengakibatkan rasa ingin tahu yang besar oleh anak, seperti halnya video porno, ceritacerita porno, tontonan televisi yang ada unsur pornonya, dan sebagainya. Sehingganya menyebabkan kejahatan kesusilaan yang dilakukan oleh anak. ${ }^{36}$

Hukum adat memiliki corak yang tradisional, keagamaan, kebersamaan, konkret dan visual, terbuka dan sederhana, dapat berubah dan menyesuaikan, tidak dikodifikasikan, musyawarah dan mufakat. Bentuk corak dari hukum adat adalah tradisional, keagamaan, kebersamaan, konkret dan visual, terbuka dan sederhana, dapat berubah dan menyesuaikan, tidak dikodifikasi, musyawarah dan mufakat. ${ }^{37}$

Berkaitan dengan pelanggaran adat atau

35 Tolib Setiadi, Intisari Hukum Adat Indonesia dalam Kajian Kepustakaan, Alfabeta, Bandung, 2008, hlm. 345.

36 Wawancara dengan Bapak Ndali Minggu, Ketua Adat Bajo, 7 Maret 2014, diolah 2014. 
delik adat, dan mekanisme pemecahannya, hukum adat memiliki pandangan tersendiri. Sebagaimana dikemukakan di atas, maka pengertian pelanggaran adat terkait dengan kondisi ketidak seimbangan kosmos dalam masyarakat. Hal ini mencakup tindakantindakan yang mengganggu kedamaian hidup atau pelanggaran terhadap kepatutan dalam masyarakat, jadi pelanggaran hukum adat tersebut merupakan: ${ }^{38}$

a. Suatu peristiwa aksi dari para pihak dalam masyarakat.

b. Aksi itu menimbulkan gangguan keseimbangan.

c. Gangguan keseimbangan itu menimbulkan reaksi.

d. Reaksi yang timbul menjadikan terpeliharanya kembali atas gangguan keseimbangan kepada keadaan semula.

Delik adat terdapat 4 (empat) unsur penting, yaitu: ${ }^{39}$

a. Ada perbuatan yang dilakukan oleh perseorangan, kelompok atau pengurus (pimpinan/pejabat) adat sendiri.

b. Perbuatan itu bertentangan dengan norma-norma hukum adat.

c. Perbuatan itu dipandang dapat menimbulkan kegoncangan karena mengganggu keseimbangan dalam masyarakat, dan

d. Atas perbuatan itu timbul reaksi dari masyarakat yang berupa sanksi adat.

Hukum adat tidak mengadakan pemisahan antara pelanggaran hukum yang mewajibkan tuntutan memperbaiki kembali hukum di dalam lapangan hukum pidana dan dilapangan hukum perdata, oleh karenanya maka sistem hukum adat hanya mengenal suatu prosedur dalam hal penuntutan yaitu baik untuk penuntutan secara perdata maupun tuntutan secara pidana (kriminal). Ini berarti bahwa petugas hukum yang berwenang untuk mengambil tindakan-tindakan konkret (reaksi adat) guna membetulkan hukum yang dilanggar itu adalah tidak seperti sistem hukum barat di mana hakim pidana menyelesaikan perkara pidana dan

Pada masyarakat adat Bajo, anak yang melakukan tindak pidana tersebut kesemuanya memiliki pendidikan rendah sehingga mudah terpengaruh oleh kecanggihan dari tekhnologi dan pembicaraan yang sering melampaui batas, berikut klasifikasi umur anak yang melakukan tindak pidana kesusilaan:

Penjelasan pada Tabel 3 klasifikasi umur anak yang melakukan tindak pidana kesusilaan di masyarakat adat Bajo, terhitung sejak tahun 2010 s/d tahun 2013 adalah anak yang melakukan tindak pidana kesusilaan di masyarakat adat Bajo adalah umur 13 tahun sebanyak 4 orang anak, dengan presentase $10 \%$, umur 14 tahun sebanyak 2 orang anak, dengan presentase 5\%, umur 15 tahun sebanyak 3 orang anak, dengan presentase $7 \%$, umur 16 tahun sebanyak 9 orang anak, dengan presentase $22 \%$, umur 17 tahun sebanyak 10 orang anak, dengan presentase $25 \%$, dan 18 tahun sebanyak 13 orang anak, dengan presentase $31 \%$.

37 Hilman Hadikusuma, Pengantar Ilmu Hukum Adat di Indonesia, Mandar Maju, Bandung, 2003, hlm. 71.

38 Eva Achjani Zulfa, Pergeseran Paradigma Pemidanaan, Lubuk Agung, Bandung, 2011, hlm. 68-69.

39 Tolib Setiadi, Op.cit., hlm. 347. 
Tabel 3. Klasifikasi Umur Anak yang Melakukan Tindak Pidana Kesusilaan pada Masyarakat Adat Bajo Tahun 2010 s/d Tahun 2013

\begin{tabular}{|c|c|r|r|}
\hline No. & Klasifikasi Umur & \multicolumn{1}{|c|}{ F } & \multicolumn{1}{c|}{$\%$} \\
\hline 1 & 13 Tahun & 4 & 10 \\
\hline 2 & 14 Tahun & 2 & 5 \\
\hline 3 & 15 Tahun & 3 & 7 \\
\hline 4 & 16 Tahun & 9 & 22 \\
\hline 5 & 17 Tahun & 10 & 25 \\
\hline 6 & 18 Tahun & 13 & 31 \\
\hline \multicolumn{2}{|c|}{ T O T A L } & $\mathbf{4 1}$ & $\mathbf{1 0 0}$ \\
\hline
\end{tabular}

Sumber: Data primer, diolah, 2014

Penyelesaian tindak pidana kesusilaan yang dilakukan oleh anak di masyarakat Adat bajo dengan menggunakan pendekatan kekeluargaan, yang melibatkan seluruh anggota yang terkait dan disaksikan oleh masyarakat setempat. Pelaku, korban, keluarga di dudukan bersama di rumah ketua adat yang disaksikan oleh masyarakat, kemudian ketua adat mencari jalan keluar yang terbaik bagi anak dan pihak keluarga. Dalam hal ini sebagian besar anak yang melakukan tindak pidana kesusilaan diberikan sanksi adat yaitu berupa dinikahkan. ${ }^{40}$

Pembetulan hukum yang dilanggar sehingga dapat memulihkan keseimbangan semula itu dapat berupa sebuah tindakan saja, berikut daftar tabel 4 mengenai sanksi adat terhadap anak yang melakukan tindak pidana kesusilaan di masyarakat Bajo, adalah sebagai berikut:

Penjelasan terhadap Tabel 4. di atas dapat dilihat bahwa, pemberian sanksi adat: berupa dinikahkan sebanyak 27 orang anak, dengan presentase $66 \%$, hal ini merupakan adanya persetujuan antara kedua belah pihak, baik pihak keluarga pelaku dan pihak keluarga korban, sedangkan memberikan sejumlah materi kepada keluarga korban dan untuk pembangunan desa, sebanyak 8 orang anak, dengan presentase 19\%, hal ini merupakan si pelaku tidak mau dinikahkan dengan korban, akan tetapi pelaku lebih memilih untuk membayar denda adat, yang nominalnya telah ditentukan oleh ketua adat, serta anak yang di Bua atau diasingkan dari desa sebanyak 6 orang anak, dengan presentase 15\%, hal ini merupakan kesepakatan yang telah diberikan oleh para tetua adat dengan mengasingkan si pelaku, karena pelaku di sini sudah berkeluarga dan melakukan tindak pidana kesusilaan.

Bapak Dali Minggu selaku Ketua Adat Bajo mengatakan bahwa dalam pemberian sanksi adat terhadap pelaku tindak pidana kesusilaan yang dilakukan oleh anak terdapat tiga tahapan: Pertama yaitu Dinikahkan, hal ini dikarenakan orang tua kedua belah pihak merasa malu atas perbuatan yang dilakukan

40 Wawancara dengan Bapak Ndali Minggu, Ketua Adat Bajo, 8 Maret 2014, diolah 2014. 
Tabel 4. Sanksi Adat atas Tindak Pidana Kesusilaan yang Dilakukan oleh Anak pada Masyarakat Adat Bajo Tahun 2010 s/d Tahun 2013

\begin{tabular}{|c|l|r|r|}
\hline No. & \multicolumn{1}{|c|}{ Sanksi Adat } & \multicolumn{1}{|c|}{ F } & \multicolumn{1}{c|}{$\%$} \\
\hline 1 & Di Nikahkan. & $\mathbf{2 7}$ & $\mathbf{6 6}$ \\
\hline 2 & $\begin{array}{l}\text { Memberikan sejumlah materi kepada keluarga kor- } \\
\text { ban dan untuk pembangunan desa. }\end{array}$ & $\mathbf{8}$ & $\mathbf{1 9}$ \\
\hline 3 & Di Bua (Di Asingkan) dari desa. & $\mathbf{6}$ & $\mathbf{1 5}$ \\
\hline T O T A L & $\mathbf{4 1}$ & $\mathbf{1 0 0}$ \\
\hline
\end{tabular}

Sumber: Data primer, diolah, 2014

oleh anak, dan keputusan yang diambil adalah untuk menikahkan keduanya sehingga menghilangkan rasa malu yang dihadapi oleh keluarga, Kedua yaitu Memberikan sejumlah materi kepada keluarga korban dan untuk pembangunan desa, jika dalam mediasi kedua belah pihak sepakat untuk memberikan denda saja, maka si pelaku hanya memberikan denda tanpa menikahi si korban, denda adat tersebut tidak hanya sejumlah uang yang telah ditentukan oleh ketua adat, tetapi si pelaku disuruh mengumpulkan sejumlah batu kecil untuk dibentangkan disepanjang jalan yang biasanya dilewati oleh masyarakat sekitar, kemudian Ketiga yaitu dengan di Bua atau diasingkan dari desa, maksud dari pemberian sanksi adat ini, dikarenakan anak sebagai pelaku di sini sudah berkeluarga dan melakukan tindak pidana kesusilaan, hal ini tidak dapat dimaafkan oleh masyarakat dan menjadi suatu keputusan dari para tetua adat untuk mengasingkan anak ke tempat yang telah ditentukan. ${ }^{41}$

Eksistensi perkembangan masyarakat hukum adat berjalan sesuai dengan perkembangan zaman. Oleh karena masyarakat adat Bajo sering berinteraksi dengan pihak luar, sekalipun masyarakat adat Bajo masih mempertahankan hukum adatnya. Akan tetapi modernisasi yang masuk di lingkungan hukum adat membuat masyarakat adat itu sudah jarang lagi mempergunakan bahasa lokal mengenai sanksi-sanksi adat Bajo.

Petugas hukum tidak selalu mengambil inisiatif sendiri untuk menindak si pelanggar hukum, dan terhadap beberapa pelanggaran hukum, petugas hukum hanya dapat bertindak apabila diminta oleh orang yang terkena. Ukuran yang dipakai hukum adat untuk menentukan manakala petugas hukum harus bertindak atas inisiatif sendiri dan manakala mereka bertindak atas permintaan orang yang bersangkutan tidak selalu sama dengan ukuran hukum barat. Dalam hukum adat petugas wajib bertindak apabila kepentingan umum atau kepentingan masyarakat langsung terkena dampaknya oleh suatu pelanggaran hukum, dan apa yang merupakan kepentingan

41 Wawancara dengan Bapak Ndali Minggu, Ketua Adat Bajo, 7 Maret 2014, diolah 2014. 
umum itu tidak selalu serupa dengan kepentingan umum menurut hukum barat, sebab dalam hukum adat segala sesuatu itu selalu berlandaskan pada nilai-nilai kemanusiaan.

Hukum pidana adat adalah hukum yang hidup (the living law), diikuti dan ditaati oleh masyarakat adat secara terus-menerus dari satu generasi ke generasi berikutnya. Pelanggaran terhadap tata tertib tersebut dipandang dapat menimbulkan kegoncangan dalam masyarakat karena dianggap dapat mengganggu keseimbangan kosmis masyarakat. Oleh sebab itu bagi si pelanggar diberikan reaksi adat, koreksi adat atau sanksi adat oleh masyarakat melalui pengurusnya.

Pengertian hukum pidana adat ini mengandung 3 (tiga) hal pokok, yaitu: ${ }^{42}$

1. Rangkain peraturan tata tertib yang dibuat, diikuti dan ditaati masyarakat adat yang bersangkutan.

2. Pelanggaran terhadap peraturan tata tertib tersebut dapat menimbulkan kegoncangan karena dianggap mengganggu keseimbangan kosmis. Perbuatan melanggar peraturan tata tertib ini dapat disebut sebagai delik adat.

3. Pelaku yang melakukan pelanggaran tersebut dapat dikenai sanksi oleh masyarakat yang bersangkutan.

Pada dasarnya anak-anak yang melakukan tindak pidana kesusilaan di masyarakat Bajo diselesaikan secara kekeluargaan, di mana ada keterlibatan pihak pelaku, korban, keluarga serta masyarakat.Untuk penyelesaian kasus terhadap anak yang melakukan tindak pidana kesusilaan.Di masyarakat adat Bajo ini anak yang tersandung kasus pidana ini, diawali dari berpacaran yang melampaui batas, kemudian diketahui oleh masyarakat setempat dan melaporkannya ke ketua adat.

Model penyelesaian tindak pidana kesusilaan yang dilakukan oleh anak ini, seluruhnya diselesaikan secara adat, tanpa melibatkan pihak kepolisian ataupun dengan menggunakan kekerasan, berikut daftar tabel model penyelesaian tindak pidana yang dilakukan oleh anak:

Penjelasan pada Tabel 5 model penyelesaian tindak pidana kesusilaan yang dilakukan oleh anak di masyarakat adat Bajo, sejak tahun 2010 s/d tahun 2013 adalah secara keseluruhan anak yang melakukan tindak pidana kesusilaan diselesaikan secara adat.

Ketua adat Bajo mengatakan dalam kasus anak keseluruhannya diupayakan menggunakan hukum adat, tanpa ada kekerasan atau keterlibatan dari pihak kepolisian. Pihak kepolisian dapat terlibat ketika di desa Jaya Bhakti telah terjadi kasus pembunuhan, penganiyayan, pencurian, masalah tanah, dan sebagainya. ${ }^{43}$

\section{Penggunaan Hukum Adat Bajo untuk Menyelesaikan Perkara Anak yang Melakukan Tindak Pidana Kesusilaan yang Mencerminkan Keadilan Restoratif}

Sifat masyarakat hukum adat berbeda dari masyarakat biasa yang ada di kota-kota, yang penting dalam hubungan tersebut untuk 
Tabel 5. Model Penyelesaian Tindak Pidana Kesusilaan yang Dilakukan oleh Anak pada Masyarakat Adat Bajo Tahun 2010 s/d Tahun 2013

\begin{tabular}{|c|l|c|c|}
\hline No. & Model Penyelesaian Sengketa & F & \% \\
\hline 1. & Diselesaikan secara adat & 41 & 100 \\
\hline T O T A L & & $\mathbf{4 1}$ & $\mathbf{1 0 0}$ \\
\hline
\end{tabular}

Sumber: Data primer, diolah, 2014

diketahui, bahwa masyarakat hukum adat kuat sifat atau alam pikiran komunalisme dan religo magis (kosmis). Hal ini menjadi penting karena menjadi latar belakang kemasyarakatan, tempat hukum pidana itu berperan.

Suatu perbuatan dianggap bertentangan dengan norma-norma hukum adat apabila perbuatan itu bertentangan dengan peraturan atau keinginan-keinginan masyarakat hukum adat setempat. Setiap ketentuan hukum adat dapat timbul dan berkembang dan dapat juga berganti dengan ketentuan yang baru, oleh karena itu, perbuatan yang dianggap bertentangan dengan norma-norma hukum adat, akan lahir dan berkembang, dan akan hilang, karena rasa keadilan dan kesadaran hukum masyarakat berubah.

Pelanggaran terhadap hukum adat diterjemahkan sebagai pelanggaran terhadap garis ketertiban kosmos tersebut. Bagi setiap orang yang dianggap menjalani hukum adat, garis ketertiban kosmos ini harus dijalani serta merta. Jika garis ini tidak dijalankan walaupun hanya oleh seorang individu maka baik masyarakat maupun orang tersebut akan menderita karena berada di luar garis tersebut.
Perbuatan ini yang disebut sebagai pelanggaran hukum adat. Begitupun penyelesaiannya dalam pandangan hukum adat, tidak ada ketentuan yang keberlakuannya disertai dengan syarat yang menjamin ketaatannya dengan jalan menggunakan paksaan, karena sanksi adat tidak sama dengan sanksi pidana.

Alam pikiran dalam masyarakat hukum yang demikian, memandang segala-galanya dalam kehidupan ini sebagai kesatuan yang homogen, di mana kedudukan manusia adalah sentral. Manusia merupakan sebagian dari alam besar (kosmos), tidak terpisah dari dunia lahir dan dunia gaib, dan berpadu dengan alam hewan dan tumbuh-tumbuhan, lebih-lebih masyarakat sendiri sebagai satu kesatuan. Jadi segala sesuatu bercampur, bersangkut paut serta saling mempengaruhi satu sama lain. Semuanya berada dalam satu keseimbangan dan senantiasa harus dijaga, dan jika pada suatu saat terganggu, harus dipulihkan.

Menggunakan hukum adat Bajo dalam penyelesaian tindak pidana terhadap anak melibatkan keselurahan pihak-pihak yang bersangkutan. Dalam hal ini suku Bajo sendiri, mengetahui ketika di desa terjadi ketidak seimbangan atau merasa desanya terganggu 
dengan adanya suatu perkara, maka setiap orang yang berperkara tersebut di arak keliling kampung dengan menggunakan bendera yang disebut Ula-Ula. Ula-Ula sendiri merupakan bendera kerajaan Sama' atau sekarang disebut dengan suku Bajo. Jiwa dari Ula-Ula adalah ambar laut atau mustika laut yang berkhasiat sebagai penawar dan juga dapat memberikan keyakinan akan tercapainya suatu tujuan. ${ }^{44}$

Menurut anggapan dan kepercayaan para leluhur terdahulu bahwa ambar laut adalah hasil pertemuan matahari dan bulan disaat gerhana, yang spermanya jatuh ke bumi. Ula-Ula sendiri berbentuk manusia, karena manusia merupakan makhluk sempurna, memiliki jiwa, memiliki hati, mempunyai akal dan pikiran, hingga selalu berkeinginan untuk bergerak maju. Ula-Ula ini digunakan oleh masyarakat bajo tersebut ketika masyarakat lingkungannya terganggu atau menggalami pencemaran. Pelaku di arak keliling kampung dengan menggunakan bendera ini, dikarenakan bendera ini bergambarkan manusia, jadi semua penyelesaian kasus dalam masyarakat Bajo ini menggunakan hati, karena yang dihadapi adalah seorang manusia. ${ }^{45}$

Ula-Ula ini terdiri dari 5 (lima) warna dan bermakna sebagai berikut:

1. Warna merah melambangkan keberanian untuk berjuang mencapai tujuan;

2. Warna putih melambangkan kesucian, kebersihan serta keikhlasan. Yaitu bersih dari pengaruh niat apapun, suci dalam niat, dan iklas dalam berkorban;

3. Warna biru melambangkan kesegaran, ketenangan untuk menatap masa depan;

4. Warna kuning melambangkan ketuaan, yang berarti berilmu, penuh pengalaman, guna menimbang-nimbang setiap langkah perjuangan menuju masa depan yang lebih baik;

5. Warna hitam melambangkan ketabahan serta kesabaran dalam menghadapi segala tantangan, demi terwujudnya suatu kehidupan yang sejahtera dan abadi.

Maka menjaga keseimbangan dan bila terancam atau tersinggung, perlu memulihkan keseimbangan itu. Sehingga dengan demikian dapat dikatakan bahwa delik adat adalah suatu perbuatan sepihak dari seorang atau sekumpulan perorangan, mengancam, menyinggung atau mengganggu keseimbangan dalam kehidupan persekutuan, bersifat material atau immaterial.

Senada dengan hukum adat Bajo yang diberlakukan terhadap anak sebagai pelaku tindak pidana kesusilaan. Hal ini hampir sama dengan shaming theory yang dikemukakan oleh seorang kriminolog Australia yaitu John Braithwaite. Braithwaite membagi shaming dalam dua jenis, yaitu stigmatization dan reintegrative. Kepekaan terhadap rasa malu tersebut di samping dapat berlanjut pada hal yang bersifat positif, yakni timbulnya keinginan pihak-pihak yang dipermalukan itu untuk segera mengintegrasikan dirinya

44 Wawancara dengan Bapak Hakim Minggu, Wakil Ketua Adat, 5 Maret 2014, diolah 2014.

45 Arsip sejarah desa Jaya Bhakti, Kecamatan Pagimana, Kabupaten Luwuk Banggai ditulis oleh Bapak Hakim Minggu pada tahun 1998, 5 Maret 2014. 
kembali ke dalam masyarakat (reintegrative shaming), dapat pula bersifat sebaliknya, yakni timbulnya keinginan dari pihakpihak yang dipermalukan itu karena merasa dikenai stigma (stigmatization), kemudian melepaskan diri dari masyarakatnya dan membentuk sub-kultur yang baru dan bisanya mengarah pada suatu kejahatan atau melibatka diri dengan sub-kultur tandingan yang sudah ada.

Titik perhatian dari teori shaming ini adalah lebih kepada reintegrative shaming. Reintegrative Shaming merupakan proses mempermalukan yang diikuti dengan upaya-upaya mengintegrasikan kembali pelaku penyimpangan atau pelanggaran hukum ke dalam masyarakat yang patuh hukum. Masyarakat akan memiliki ratarata angka kejahatan yang rendah apabila mereka menerapkan shaming secara efektif dalam menangani kejahatan. Karakteristik Reintegrative Shaming menurut Braithwaite adalah jika masyarakat: ${ }^{46}$

a. Menolak atau mencela tingkah laku jahat, memuji atau mendukung tingkah laku baik.

b. Memiliki formalitas yang menyatakan tingkah laku seseorang jahat atau menyimpang, yang diakhiri dengan menyatakan orang tersebut sudah dimaafkan.

c. Memberikan hukuman atau pencelaan tanpa proses labelling.

d. Tidak menjadikan kesalahan atau penyimpangan atau kejahatan sebagai dari status utama (master status trait).
Sehubungan dengan teori yang dikemukakan oleh John Braithwaite, maka dalam penggunaan sanksi terhadap anak yang melakukan tindak pidana kesusilaan di Bajo, lebih mengutamakan pada penciptaan rasa malu yaitu shaming reintegrative theory di mana tujuan dari teori ini untuk pemberian rasa malu terhadap pelaku, atau pelaku disalahkan masyarakat dengan adanya suatu kejahatan, akan tetapi menarik kembali pelaku dengan ketertiban sosial. Sama halnya dengan anak yang melakukan kejahatan pada suku Bajo, anak tersebut di arak keliling kampung dengan menggunakan bendera Ula-Ula ini, dimaksudkan agar masyarakat mengetahui bahwa di desa telah terjadi suatu pelanggaran. Hal ini dapat menciptakan rasa malu terhadap anak, tetapi menarik kembali anak dalam masyarakat.

Tindakan atau perbuatan yang demikian mengakibatkan reaksi adat yang dipercaya dapat memulihkan keseimbangan yang telah terganggu, antara lain dengan berbagai cara dan jalan, dengan pembayaran adat berupa barang, uang, mengadakan selamatan, memotong hewan besar atau kecil, dan lainlain. ${ }^{47}$ Lazimnya dalam masyarakat hukum adat dapat diambil kesimpulan bahwa bilamana dan apa unsurnya untuk tampil sesuatu delik adat sulit ditemukan. Sangat tergantung dari representations collectives yaitu alam pikiran dalam masyarakat, merupakan perpaduan dari nilai-nilai yang ada di dalam masyarakat, selalu bersifat partisipasi dan analisa (partisiperend en analiserend).

46 Achmad Ratomi, Shaming Theory, http://achmadratomi.blogspot.com/2013/05/normal-0-false-false-falseen-us-X-none.html, diakses 30 April 2014 pukul 10.10 WIB. 
Pada dasarnya bahwa nilai-nilai yang ada dalam masyarakat hukum adat Bajo itu, sama halnya dengan prinsip-prinsip dasar yang terdapat pada restorative justice di mana keadilan sebagai proses untuk pemecahan sebuah masalah dan melibatkan keseluruhan pihak-pihak yang terkait tanpa melibatkan pihak kepolisian sebagai aparat penegak hukum. Bagi tindak pidana yang dilakukan oleh anak atau remaja, maka pendekatan ini sangat cocok sebagai media untuk mengajarkan nilai-nilai baru bagi pelaku yang masih muda. Karenanya dalam penanganan tindak pidana dengan menggunakan respon ini, maka aturan tata tingkah laku dalam masyarakat menjadi hal yang utama dan penting dalam usaha mencegah dan merespon kejahatan serta tingkah laku menyimpang dalam masyarakat.

F.D. Holleman mengatakan bahwa, di Indonesia ada 4 sifat umum hukum adat, yaitu: 48

a. Sifat religio magis atau kepercayaan, yaitu pembulatan atau perpaduan kata yang mengandung unsur beberapa sifat atau cara berfikir seperti prelogika, animism, pantangan, ilmu ghaib, dan lain-lain.

b. Sifat komus atau umum, yaitu sifat yang mendahulukan kepentingan umum dari pada kepentingan pribadi.

c. Sifat kontan atau tunai, yaitu dengan suatu perbuatan nyata atau simbolis atau mengucapkan, tindakan hukum yang dimaksud telah selesai seketika itu juga.

d. Sifat kongkrit atau nyata, yaitu dalam alam berpikir yang tertentu senantiasa dicoba dan diusahakan, agar hal-hal yang dimaksud diinginkan atau akan dikerjakan, diberi wujud nyata dalam bentuk benda, dan diberi tanda nyata sesuai dengan obyek yang dikehendaki (simbolis, benda-benda magis).

Konsep hukum adat sebagai wadah dari institusi peradilan adat juga memiliki konsep yang dapat digambarkan sebagai akar dari keadilan restoratif. Karakteristik dari hukum adat disetiap daerah pada umumnya amat mendukung penerapan keadilan restoratif. Hal ini dapat dilihat dari ciri-ciri umum hukum adat terhadap pelanggaran adat/delik adat serta model dan cara penyelesaian yang ditawarkan.

Soepomo mendeskripsikan ciri umum tersebut sebagai berikut: ${ }^{49}$

a. Corak religius yang menempatkan hukum adat sebagai bentuk kesatuan batin masyarakat dalam suatu persekutuan (komunal).

b. Sifat komunal dari hukum adat menempatkan individu sebagai orang yang terikat dengan masyarakat. Seorang individu bukanlah sosok yang bebas dalam segala tingkah laku karena dibatasi oleh batasan-batasan norma yang telah diterapkan baginya.

c. Tujuan dari persekutuan masyarakat adalah memelihara keseimbangan lahir batin antara individu, golongan dan lingkungan hidupnya (levemilieu). Tujuan ini pada dasarnya diemban oleh masing-masing individu anggotanya demi mencapai tujuan dari persekutuan.

d. Tujuan memelihara keseimbangan lahir batin berangkat dari pandangan atas ketertiban yang ada dalam alam semesta

47 Bushar Muhamad, Pokok-pokok Hukum Adat, Balai Pustaka, Jakarta, 2013, hlm. 61-62.

48 E.S. Ardinato, Mengenal Adat Istiadat Hukum Adat di Indonesia, UNS Press, Surakarta, 2008, hlm. 43.

49 Eva Achjani Zulfa, Loc.cit., hlm. 68. 
(kosmos), dimana ketertiban masyarakat merupakan bentuk hubungan harmonis antara segala sesuatu. Gerak dan usaha memenuhi kebutuhan individu adalah merupakan gerak dan usaha yang ditetapkan dalam garis kosmos itu.

e. Pelanggaran terhadap hukum adat diterjemahkan sebagai pelanggaran terhadap garis ketertiban kosmos tersebut. Bagi setiap orang yang dianggap menjalani hukum adat, garis ketertiban kosmos itu harus dijalani secara serta merta. Jika garis ini tidak dijalankan walaupun hanya oleh seorang individu maka baik masyarakat maupun orang terebut akan menderita karena berada di luar garis tersebut. Perbuatan ini yang disebut dengan pelanggaran adat.

Tujuan utama keadilan restoratif adalah menciptakan pemulihan hubungan sosial dalam masyarakat. Hal yang mustahil dilaksanakan bila proses penanganan perkara pidana dengan pendekatan keadilan restoratif justru mengancam keselamatan masyarakat, menjadikan masyarakat tidak terlindungi, menimbulkan kerusakan atau menimbulkan disharmonisasi masyarakat akibat tindak pidana yang tengah diselesaikan oleh tindak pidana ini. Oleh karena itu pertimbangan keamanaan masyarakat harus menjadi pertimbangan utama yang diberikan sehingga proses yang terjadi mampu berakibat positif bagi masyarakat, tidak mengancam keamanan, menimbulkan ketakutan apalagi mengancam keharmonisan hubungan sosial dalam masyarakat.

Pada dasarnya penyelesaian perkara pidana dengan menggunakan pendekatan keadilan restoratif adalah merupakan satu pilihan yang ditawarkan bukan berarti bahwa dengan hadirnya pendekatan baru yaitu keadilan restoratif, sistem peradilan pidana konvensional akan menjadi hilang. Kehadiran sistem peradilan pidana masih dianggap perlu, manakala pendekatan keadilan restoratif tidak dapat mencapai hasil yang diinginkan.

Meskipun demikian, pilihan penyelesaian perkara pidana dengan menggunakan pendekatan restoratif ini dapat juga menjadi bingkai bagi bekerjanya sistem peradilan pidana konvensional. Karena pada dasarnya proses penyelesaian perkara pidana dengan menggunakan pendekatan keadilan restoratif khususnya dalam hukum adat merupakan suatu proses dalam rangka mencari bentuk terbaik dari suatu penyelesaian atas sengketa yang terjadi di dalam masyarakat, apakah dilaksanakan secara mandiri oleh masyarakat atau dengan melibatkan sistem peradilan pidana.

Manusia menurut ajaran adat, wajib mendudukkan rasa malu sebagai basis nilai di dalam setiap hubungan sosialnya. Ajaran moral tahu malu inilah yang di dalam perspektif hukum adat menjadi semacam mekanisme pertahanan atau pengekangan diri, agar manusia tidak berbuat sesuatu yang bertentangan dengan kepatutan, kerukunan, dan keselarasan dalam hidup bermasyarakat. Ajaran tahu malu yang ditanamkan kepada individu-individu, pada dasarnya memberikan suatu landasan yang fundamental kepada meraka yang terlibat dalam setiap perhubungan sosial. Ajaran tahu malu ini berfungsi sebagai 
basis nilai di dalam setiap perhubungan sosial, dengan tujuan agar mereka yang melakukan hubungan sosialnya dapat menempatkan dirinya secara patut.

Pemeliharaan norma kesusilaan dan kesopanan dalam masyarakat secara bersamasama melahirkan suatu solidaritas berwujud usaha pencegahan terjadinya delik. Jika suatu delik telah nyata-nyata dilakukan oleh individu dan telah memenuhi unsur kausalitasnya maka reaksi yang merupakan koreksi adalah tindakan otomatis yang menjadi keharusan demi keseimbangan masyarakat. Cakupan perbuatan-perbuatan yang dapat dikatakan sebagai delik adat sangatlah luas, namun suatu delik hanya berlaku di dalam masyarakat yang bersangkutan. Suatu delik yang lahir dan tumbuh dalam suatu masyarakat hanya berlaku di wilayah masyarakat tersebut. Walaupun demikian, hal ini bukan berarti hanya berlaku khusus bagi warga masyarakat yang bersangkutan.

Ada dua hal yang membatasi wilayah berlakunya hukum adat secara teritorial. Pertama, kebudayaan yang ada di dalam masyarakat yang bersangkutan. Hal ini dikarenakan pada dasarnya delik adat merupakan sebuah aspek dari kebudayaan. Kedua, masyarakat tempat lahir, tumbuh, berkembang, dan lenyapnya delik adat. Relevansinya bahwa suatu delik adat dipandang sebagai delik atau bukan sangat bergantung pada struktur masyarakatnya. ${ }^{50}$

Delik yang dimaksud adalah perbuatan sepihak yang merongrong integritas manusia maupun benda. Jadi, delik adat meliputi kejahatan maupun pelanggaran. Menurut literatur-literatur hukum adat, perbuatan main hakim sendiri dikenal dalam hukum adat. Namun, hanya dapat dilakukan oleh subjek yang menjadi korban atau secara langsung menderita kerugian akibat delik yang dilakukan orang lain. Itupun ada syaratnya, yaitu pelakunya tertangkap tangan seketika sedang melakukan suatu delik. Tetapi aturan ini hanya berlaku pada zaman dahulu kala.

Atas dasar alam pikiran kosmis yang mendasari hukum adat, maka yang dapat dikategorikan sebagai delik adat adalah setiap perbuatan yang mengganggu atau mengakibatkan kegoncangan alam semesta, yang selalu terjaga harmonisnya. Pada prinsipnya, harmoni alam semesta ini diwujudkan dalam harmoni manusia. Jika harmoni dalam kehidupan bersama dalam masyarakat terganggu, maka harmoni alam semesta juga ini akan terganggu. Hal ini dikarenakan manusia adalah bagian yang tak terpisahkan dari alam semesta.

Manakala muncul gangguan akibat adanya delik dalam masyarakat, adat memberikan reaksi berupa koreksi. Koreksi ini ditujukan kepada seluruh anggota masyarakat, baik pelaku delik maupun bukan. Koreksi

50 Anto Soemaman, Hukum Adat Perspektif Sekarang dan Mendatang, Mitra Gama Widya, Yogyakarta, 2003, hlm. 11-12. 
diperlukan karena delik dianggap sebagai wujud keluarnya sesuatu dari garis tertib kosmis. Pada dasarnya koreksi ini tidak sama dengan sanksi, sekalipun wujud konkretnya seperti sanksi. Disinilah ciri khas hukum adat yang dari konseptualnya memberikan koreksi dengan sanksi.

Koreksi adat terhadap perbuatan delik ditujukan secara nyata kepada pelaku delik. Hubungan seks di luar ikatan perkawinan antara seorang bujang dan seorang gadis atas dasar suka sama suka sekalipun termasuk delik adat. Oleh sebab itu, perlu diberikan koreksi. Koreksi yang berwujud nyata seperti sanksi bagi pelaku seks semacam ini pada masing-masing lingkungan hukum tidak sama, tergantung pemahaman masyarakat terhadap nilai-nilai yang menjadi dasarnya.

Pada umumnya, jika terjadi seks di luar nikah, koreksinya berupa permintaan maaf, pembayaran denda, dan membasuh desa. Kesemuanya itu bermakna pembersihan diri dari segala kotoran agar kembali lagi ke dalam garis tertib kosmis. Namun, di daerahdaerah tertentu ada yang menghukum pelaku hubungan seks ini dengan pengucilan atau bahkan dibunuh. Jika delik ini dilakukan oleh subjek yang sama untuk kesekian kalinya. Di masyarakat adat Bajo sendiri anak yang melakukan tindak pidana kesusilaan, oleh ketua adat diberikan sanksi adat dengan beberapa klasifikasi, yaitu: 1. Dinikahkan; 2. Memberikan sejumlah materi untuk keluarga korban dan/atau untuk pembangunan desa; dan 3. Di Bua (diasingkan) dari desa. Namun demikian, yang tidak dapat diabaikan dalam masalah koreksi adalah adanya bukti, baik berupa saksi maupun pengakuan dari pelaku.

Hukum adat merupakan bagian atau aspek dari adat. Adat adalah pengetahuan hidup yang berupa ajaran-ajaran sosial yang penuh dan syarat dengan nilai-nilai. Adat diturunkan dari generasi ke generasi secara faktual, yaitu dengan cara melihat dan melaksanakan perilaku-perilaku terpujinya, sebagai suatu sistem ajaran, adat menghendaki agar manusia-manusia berpartisipasi dapat menyadari eksistensinya sebagai bagian yang tak terpisahkan dari alam semesta, yang tugas pokoknya membuat kebaikan-kebaikan bagi dunia. Dalam peringkatkehidupan masyarakat, adat mengajarkan bagaimana manusia harus berperilaku agar tahu malu. Dengan demikian, hukum adat yang merupakan salah satu aspek adat tidak terlepas dari karakter adat. Koreksi hukum adat sendiri sendiri tidak terlepas juga dari basis agar manusia tahu malu, sehingga tidak melakukan perbuatan-perbuatan yang memalukan.

Adat adalah wujud idiil dari kebudayaan, yang berfungsi sebagai pengatur tingkah laku manusia. Dalam kedudukannya sebagai wujud idiil kebudayaan, adat dapat dibagi lebih khusus dalam empat tingkat, yaitu: ${ }^{51}$

(6) Tingkat nilai budaya, yaitu adat dalam tingkat nilai memiliki ruang lingkup paling abstrak dan paling luas. Dalam tingkat ini adat merupakan sekumpulan ide-ide yang menkonsepsikan hal-hal yang paling bernilai dalam kehidupan masyarakat, karena kedudukan dan sifatnya, biasanya konsepsi-konsepsi yang timbul dari padanya menjadi kabur 
dan irasional. Walaupun demikian, yang irasional inilah yang menjadi akar yang paling penting dalam jiwa manusia.

(7) Tingkat norma-norma, yaitu sudah berkaitan dengan peranan-peranan dalam masyarakat. Adat memberikan perdoman-pedoman terhadap manusia sehubungan dengan peranan-peranannya dalam kehidupan bermasyarakat.

(8) Tingkat hukum, yaitu adat lebih jelas warna dan kehendaknya. Karena adat dalam peringkat hukum tidak lagi berfungsi memberikan pedoman kepada kehidupan manusia, tetapi mengaturnya. Hukum adat sebagai suatu sistem hukum yang merupakan endapan dari rasa susila dan kesopanan serta berdasarkan kaidah rukun dan hormat.

(9) Tingkat aturan-aturan khusus, yaitu sistem hukum yang berlaku pada suatu masyarakat lebih mengkongkretkan dengan memberikan aturan-aturan yang khusus dalam aktifitas manusia.

Keadilan restoratif dalam hal ini dinyatakan sebagai suatu mekanisme yang telah ada dalam masyarakat tradisional. Namun nilai-nilai kearifan lokal yang beragam menimbulkan pandangan yang berbeda dalam memaknai terjadinya suatu tindak pidana dan terhadap tindak pidana itu sendiri. Keadilan restoratif sendiri pada dasarnya dinyatakan sebagai suatu kearifan lokal yang sifatnya universal.

Maknanya adalah bahwa nilai dasar dari keadilan restoratif berupa perdamaian hubungan sosial merupakan nilai yang ada dalam masyarakat di dunia. Hanya saja interpretasi nilai ini yang dianggap menjadi beragam dalam tataran praktis dan menimbulkan persoalan. Persoalan yang muncul adalah pihak-pihak yang terlibat berasal dari masyarakat yang berbeda. Dibutuhkan suatu kajian sosial yang mendalam sehubungan dengan masalah ini. Ikatan pemahaman bersama sebagai wujud solidaritas sosial dianggap dapat menjadi perekat pelaksanaan proses sehingga selayaknya hal ini dikedepankan.

\section{Simpulan}

1. Bentuk penyelesaian hukum adat Bajo terkait dengan tindak pidana kesusilaan yang dilakukan oleh anak, semuanya diselesaikan secara adat Bajo, tanpa melibatkan pihak kepolisian ataupun dengan jalan kekerasan.

2. Dalam hal penggunaan hukum adat Bajo, ketika masyarakat mengetahui adanya kegoncangan/kerusuhan/pelanggaran yang terdapat di desa mereka, maka anak yang melakukan tindak pidana kesusilaan atau pelaku di arak keliling desa dengan menggunakan bendera yang disebut Ula-Ula. Maksud dari di arak keliling desa ini adalah untuk pemberian rasa malu terhadap pelaku, atau pelaku disalahkan masyarakat dengan adanya suatu kejahatan, akan tetapi menarik kembali pelaku dalam masyarakat. Setelah di arak keliling desa, oleh ketua adat diberikan sanksi adat, terdapat 3 sanksi adat yang dapat diberikan oleh punggawa selaku 
ketua adat, yang pertama bisa dinikahkan, kedua menyerahkan sejumlah materi kepada keluarga korban (ganti rugi) dan untuk pembangunan desa, yang ketiga di Bua atau diasingkan.

\section{DAFTAR PUSTAKA}

Buku

Anto Soemarman, 2003, Hukum Adat Perspektif Sekarang dan Mendatang, Mitra Gama Widya, Yogyakarta.

Barda Nawawi, 2010, Mediasi Penal Penyelesaian Perkara di Luar Pengadilan, Pustaka Magister,

Semarang.

Bushar Muhamad, 2013, Pokok-pokok Hukum Adat, Balai Pustaka, Jakarta.

Dewi Wulansari, 2012, Hukum Adat Indonesia, Suatu Pengantar, Refika Aditama, Bandung.

E.S. Ardinato, 2008, Mengenal Adat Istiadat

Hukum Adat di Indonesia, UNS Press, Surakarta.

Eva Achjani Zulfa, 2011, Pergeseran Paradigma Pemidanaan, Lubuk Agung, Bandung.

Fatahillah Syukur, 2012, Mediasi Yudisial di

Indonesia, Mandar Maju, Bandung.

Hilman Hadikusuma, 2003, Pengantar IImu

Hukum Adat di Indonesia, Mandar Maju, Bandung.

I Made Widnyana, 1993, Kapita Selekta

Hukum Pidana Adat, Eresco, Bandung.

Marlina, 2012, Peradilan Pidana Anak di Indonesia, Pengembangan Konsep

Diversi dan Restorative Justice, Refika Aditama, Bandung.

M. Nasir Djamil, 2013, Anak Bukan untuk
Dihukum, Sinar Grafika, Jakarta.

P.A.F. Lamintang, 1997, Dasar-dasar Hukum

Pidana Indonesia, Citra Aditya Bakti, Bandung.

Romli Atmasasmita, 2010, Teori dan Kapita

Selekta Krominologi, Refika Aditama, Bandung.

Siswanto Sunarso, 2012, Viktimologi dalam

Sistem Peradilan Pidana, Sinar Grafika, Jakarta.

Takdir Rahmadi, 2010, Mediasi Penyelesaian

Mufakat, RajaGrafindo Persada, Jakarta.

Tolib Setiadi, 2008, Intisari Hukum Adat Indonesia dalam Kajian Kepustakaan, Alfabeta, Bandung.

Makalah

I Nyoman Nurjaya, Artikel (Kewenangan Diskresi dan Diversi Polisi dalam Tugas Penegakkan Hukum Pidana), Makalah dipresentasikan dalam Seminar Kepolisian dengan Tema "Penegakan Hukum Selektif oleh
Sengketa Melalui Pendekatan 
Polri: Keniscayaan Yang Tidak Diakui, Undang-undang Republik Indonesia Nomor

Legalitas dan Relevansinya dengan Kepastian Hukum", diselenggarakan dalam rangka Hari Ulang Tahun Bhayangkara Ke 67 Tahun 2013 oleh Kepolisian Resort Blitar Kota, 5 Juni 2013, Gedung Kusuma Wicitra Kota Blitar.

\section{Peraturan Perundang-undangan}

Kitab Undang-undang Hukum Acara Pidana.

Kitab Undang-undang Hukum Pidana.

Undang-undang Nomor 3 Tahun 1997 tentang Pengadilan Anak.

Undang-undang Republik Indonesia Nomor 2 Tahun 2002 tentang Kepolisian. 23 Tahun 2002 tentang Perlindungan Anak.

Undang-undang Nomor 11 Tahun 2012 tentang Sistem Peradilan Pidana Anak.

\section{Naskah Internet}

Achmad Ratomi, Shaming Theory, http:// achmadratomi.blogspot.com/2013/05/ normal-0-false-false-false-en-us-Xnone.html. 